\title{
Immunoprotective Human Monoclonal Antibodies against Five Major Serotypes of Pseudomonas aeruginosa
}

\author{
By SHUZO SAWADA, TAKASHI KAWAMURA AND \\ YASUHIKO MASUHO* \\ Teijin Institute for Biomedical Research, Hino, Tokyo 191, Japan
}

(Received 27 April 1987; revised 29 June 1987)

\begin{abstract}
Human monoclonal antibodies (Mabs) against the $\mathrm{O}$ antigens of Pseudomonas aeruginosa lipopolysaccharides (LPS) were produced by cell fusion between human tonsillar lymphocytes and P3-X63-Ag8-U1 (P3U1) mouse myeloma cells. To obtain human Mabs efficiently, $6 \mathrm{~d}$ culture supernatants of pokeweed-mitogen-stimulated lymphocytes (21 cultures from peripheral blood and 76 from tonsils) were assayed by ELISA. Five tonsillar lymphocytes which produced IgG antibody specific for $P$. aeruginosa LPS were preselected for fusion. The human Mabs, named P1-1 (IgG2, $\kappa$ ), P5-1 (IgG2, $\lambda$ ), P7-1 (IgG2, $\lambda)$, P8-1 (IgG2, $\lambda)$ and P10-1 (IgG2, $\kappa)$, bound with high specificity to Homma standard serotype strains A, E, B, G and I, respectively, and recognized $\mathrm{O}$ antigens. Each $\mathrm{Mab}$ showed opsonophagocytic killing activity of the corresponding serotype strain. Four of the Mabs caused agglutination at a very low concentration; a rather higher concentration of P7-1 was required for this effect. Although all the Mabs conferred type-specific protection against peritoneal infection, the strongly agglutinating Mabs provided better protection than the moderately agglutinating P7-1. The protective activity of P8-1 was estimated in compromised mice. A low dose $\left(\mathrm{PD}_{50} 0.5-0.6 \mu \mathrm{g}\right.$ per mouse) of P8-1 prevented subcutaneous infection in burned mice and peritoneal infection in leucopenic mice. All the hybridomas described here could be cultured in serum-free medium, and they have continued to secrete human Mabs for more than 14 months at rates of $10-20 \mu \mathrm{g}$ per $10^{6}$ cells in $24 \mathrm{~h}$. These results suggested that these five human Mabs specific for $\mathrm{O}$ antigens might be useful in the prophylaxis and treatment of $P$. aeruginosa infections.
\end{abstract}

\section{INTRODUCTION}

Pseudomonas aeruginosa infections frequently occur in compromised hosts (Hoiby \& Olling, 1977; Pruit, 1974; Bodey \& Rodriquez, 1973), and a high incidence of morbidity and mortality are associated with these infections. Antibiotic therapy of these patients is not always successful because the causative organisms are often resistant to drugs (Lowbury \& Jones, 1975; King et al., 1983), and alternative methods for treatment and prevention of Pseudomonas infections are increasingly being sought. Passive immunotherapy with antibodies is thought to have potential (Fisher, 1977; Cryz et al., 1983).

We have been interested in the protective activity of monoclonal antibodies (Mabs) against $P$. aeruginosa infection, and have demonstrated the protective activity of several mouse Mabs that recognize the lipopolysaccharide (LPS) of $P$. aeruginosa (Sawada et al., 1984). Recently, other investigators have also reported high protective activity of mouse Mabs specific for $P$. aeruginosa LPS (Stoll et al., 1986; Barclay et al., 1986). For potential treatment or prophylaxis,

\footnotetext{
Abbreviations: A-PS, acid-treated LPS; FCS, foetal calf serum; HBSS-Gel, Hanks' balanced salt solution containing $0 \cdot 1 \%$ gelatin; Mab, monoclonal antibody; NHIgG, normal human serum IgG; PBL, peripheral blood lymphocytes; $\mathrm{PD}_{50}$, mean protective dose; PMN, polymorphonuclear leucocytes; $\mathrm{PWM}$, pokeweed mitogen; i.p., intraperitoneal(ly); s.c., subcutaneous(ly).
} 
however, a human Mab should be developed, because a mouse Mab is a foreign protein in man. We first developed a human Mab against the LPS of the Homma standard serotype E strain of $P$. aeruginosa through fusion of human tonsillar cells and mouse myeloma cells, and confirmed its protective ability (Sawada et al., 1985a). However, in that work we did not study opsonic activity and examined only one human Mab, against serotype E. There are as many as $17 P$. aeruginosa serotypes (Liu et al., 1983), each determined by its O polysaccharide; thus treatment of $P$. aeruginosa infections with human Mabs would ideally require 17 kinds of human Mab. Our attempt to prepare these, however, had to be abandoned because it was time-consuming and inefficient. Instead, we decided to develop five kinds of human Mab binding to the major serotypes of LPS, i.e. A, B, E, G and I, which are frequently detected in patients in Japan (Sato et al., 1981) and are thought to account for $70-80 \%$ of all $P$. aeruginosa strains. In the work described here, we developed five specificities of human Mab which bind to $\mathrm{O}$ antigens and evaluated their biological activities in vitro and in vivo.

\section{METHODS}

Bacterial strains. Homma standard serotype strains of $P$. aeruginosa (ATCC 27577-90) and Fisher immunotype strains (ATCC 27312-18) were purchased from the American Type Culture Collection (Bethesda, Md, USA). $P$. aeruginosa NC5 (serotype G) was a gift from Dr J. Y. Homma, Kitasato Institute, Tokyo. The other strains used for this study were from our laboratory collection. All strains were cultured in heart infusion agar or broth (Nissui Pharmaceuticals) at $37^{\circ} \mathrm{C}$. Serotypes A, B, E, G and I described here are thought to be similar to 3, 2 and 5, 11, 6 and 1 , respectively, in the international typing scheme.

Preparation of human Mabs. Human peripheral blood lymphocytes (PBL) were obtained from 21 patients with $P$. aeruginosa infections and tonsillar cells were prepared from tonsils surgically removed from 76 patients with tonsillitis. The lymphocytes were separated with a Ficoll-Paque solution (Pharmacia). To determine the ability of these lymphocytes to give a high yield of hybridomas which would secrete human Mabs specific for $P$. aeruginosa LPS, $1 \times 10^{6}$ lymphocytes were suspended in $1 \mathrm{ml}$ RPMI 1640 medium (Gibco) containing 2 mM-L-glutamine, $1 \mathrm{~mm}$-sodium pyruvate, $0.2 \mathrm{~mm}$-L-serine, $80 \mu \mathrm{g}$ gentamicin sulphate (Schering) $\mathrm{ml}^{-1}$, and $10 \%(\mathrm{v} / \mathrm{v}$ ) foetal calf serum (FCS) (General Scientific Laboratories). To this cell suspension, pokeweed mitogen (PWM) (Gibco) was added to a concentration of $10 \mu \mathrm{g} \mathrm{ml}^{-1}$. Samples $(1 \mathrm{ml})$ of this cell suspension were transferred into flat-bottomed 24-well plates (Costar 3424) and cultured at $37^{\circ} \mathrm{C}$ for $6 \mathrm{~d}$ in an incubator with an atmosphere of $5 \% \mathrm{CO}_{2}$ and $95^{\circ} \%$ air. The $6 \mathrm{~d}$ culture supernatants were assayed by ELISA for the amount of human antibodies specific for $P$. aeruginosa LPS.

Human lymphocytes which produced a high antibody titre were selected for use in fusion with mouse myeloma cells. The selected human lymphocytes were cultured in the same medium for $4 \mathrm{~d}$ and then washed once with serum-free RPMI 1640 medium. Lymphocytes $\left(5 \times 10^{6}\right)$ were fused with $5 \times 10^{6}$ nonsecreting mouse myeloma P3-X63-Ag8-Ul (P3U1) (Yelton et al., 1978), which was provided by Dr M. Taniguchi (Chiba University, Japan), in $1 \mathrm{ml}$ fusion solution consisting of $35 \%(\mathrm{v} / \mathrm{v})$ polyethylene glycol 1500 (Wako Pure Chemicals) and $7 \cdot 5 \%(\mathrm{v} / \mathrm{v})$ dimethyl sulphoxide in serum-free RPMI 1640 medium. The fused cells were dispensed into a 96 -well tissue culture plate (Costar 3596) at a concentration of $2 \times 10^{4}$ cells per well and cultured in the above medium containing $\mathrm{I} \times 10^{-4} \mathrm{M}$-hypoxanthine, $4 \times 10^{-7} \mathrm{M}$-aminopterin and $\mathrm{I} .6 \times 10^{-5} \mathrm{M}$-thymidine. The medium was changed once a week. Hybridomas were cloned by limiting dilution to give $0 \cdot 3$ cells per well. The hybridoma culture supernatants were tested for antibody to $P$. aeruginosa cells by ELISA as described below. Hydridoma cells were also cultured in serum-free medium, the composition of which is described by Murakami et al. (1982).

The culture supernatant of each hybridoma was separately pooled and precipitated with ammonium sulphate (final saturation, $50 \%$ ), and after dialysis against phosphate-buffered saline (PBS) it was subjected to Protein ASepharose (Pharmacia) column chromatography. The eluted human Mab gave two protein bands identical to the heavy and light chains of immunoglobulin G (IgG) in SDS-PAGE (12.5\%, w/v, acrylamide slab gels) (Laemmli, 1970), and no other contaminating protein bands were observed. We calculated the IgG concentration of the purified materials by measuring the absorption at $280 \mathrm{~nm}$ or by the single radial immunodiffusion method with an LC-Partigen-IgG plate (Behring-Werke). This purified material was used for the experiments on the biological activities in vitro and in vito. The isotype of each human Mab was determined by immunodiffusion in human immunoglobulin RID plates (Serotec) and by ELISA with goat antibodies to human $\lambda$ and $\kappa$ chains (Tago).

Preparation of pooled normal human serum $\operatorname{IgG}(\mathrm{NHIgG})$. Plasma, collected from more than 1000 normal blood donors, was fractionated with ethanol at the Chemo-Sero Therapeutic Research Institute (Kumamoto, Japan). 
Screening for human Mabs by ELISA. To screen for Mabs specific for $P$. aeruginosa, we performed ELISA with plates coated with a mixture of strains of the five major serotypes (Homma strains ATCC 27577, 27578, 27581, $27583,27584,27586$ and 27589). The ELISA procedure was as described previously (Sawada et al., 1985a). To determine the specificities of the Mabs, we coated Homma standard serotype strains, Fisher Immunotype strains, 48 clinical isolates of $\boldsymbol{P}$. aeruginosa and other Gram-negative bacterial strains such as Escherichia coli or Salmonella minnesota onto 96-well plates, and measured the binding of the Mabs to these antigens by ELISA. For the binding of LPS to 96-well plates, $50 \mu \mathrm{l}$ of $1 \mu \mathrm{g} \mathrm{LPS} \mathrm{ml} \mathrm{m}^{-1}$ in distilled water was added to 96-well flat plates, dried and fixed to the plates at $70^{\circ} \mathrm{C}$ for $5 \mathrm{~h}$. The wells were washed twice with PBS and filled with PBS containing $1 \%(\mathrm{w} / \mathrm{v})$ bovine serum albumin, and the plates were stored at $4^{\circ} \mathrm{C}$.

Preparation of LPS. P. aeruginosa was cultured to the late-exponential phase in $101 \mathrm{~L}$-broth (Bertani, 1951). The cells were killed by addition of formaldehyde to a concentration of $0.3 \%$, harvested by centrifugation at $8000 \mathrm{~g}$ for $7 \mathrm{~min}$, washed once with distilled water and lyophilized. LPS was extracted by the hot phenol/water method of Johnson \& Perry (1976). LPS was prepared from strains N-2 (serotype E), IT1 (G), PAO-1 (B), ATCC 27577 (A) and ATCC $27586(\mathrm{I})$. All the LPS preparations contained $<0.3 \%(w / w)$ protein and $<0.25 \%(w / w)$ nucleic acid.

Determination of antigen recognition site of human Mabs. LPS was hydrolysed with $1 \%(\mathrm{v} / \mathrm{v})$ acetic acid at $100{ }^{\circ} \mathrm{C}$ for $2 \mathrm{~h}$ in a closed ampoule to prepare acetic-acid-treated LPS (A-PS) as described previously (Sawada et al., $1985 b$ ). A-PS preparations from various strains of $P$. aeruginosa were subjected to column chromatography on Sephadex G-50 (Pharmacia) and eluted with $50 \mathrm{~mm}$-pyridine/acetic acid buffer ( $\mathrm{pH} \mathrm{4.2).} \mathrm{The} \mathrm{contents} \mathrm{of}$ hexosamine and hexose in each fraction were determined as described previously (Sawada et al., 1985b). Each fraction was used in competitive inhibition of the binding of each human Mab to $P$. aeruginosa in order to determine the Mab recognition site. The percentage of residual activity was calculated as described previously (Sawada et al., 1985b). The fractions containing $O$ antigen were determined by the binding inhibition test using rabbit antiserum specific for the $O$ antigen of $P$. aeruginosa (Denka Seiken Co.).

Agglutination test. This was done by mixing $100 \mu \mathrm{l}$ of a twofold serial dilution series (starting from $100 \mu \mathrm{g} \mathrm{ml}^{-1}$ ) of each human Mab and $50 \mu \mathrm{l}$ of $10^{9}$ formalin-killed $P$. aeruginosa $\mathrm{ml}^{-1}$. The mixture was left for $3 \mathrm{~h}$ or overnight at room temperature, and the agglutination activity was expressed as the endpoint concentration of human Mab that gave agglutination.

Opsonophagocytic killing assay. $P$. aeruginosa strains were grown in heart infusion broth for $4 \mathrm{~h}$ at $37^{\circ} \mathrm{C}$. The cultures were suspended in Hanks' balanced salt solution containing 0.1\% gelatin (HBSS-Gel). The concentration was adjusted spectrophotometrically to approximately $1 \times 10^{7}$ c.f.u. $\mathrm{ml}^{-1}$. Human polymorphonuclear leucocytes (PMN) were prepared from PBL obtained from a healthy donor. The concentration was adjusted to approximately $1 \times 10^{7}$ cells per ml of HBSS-Gel. Human serum, obtained from the same donor, was absorbed for $1 \mathrm{~h}$ at $0^{\circ} \mathrm{C}$ with each of the $P$. aeruginosa strains used for these experiments and diluted 1 in 40 with HBSS-Gel. This absorbed human serum was used as the complement source. The concentration of human Mab was adjusted to $40 \mu \mathrm{g} \mathrm{ml}$ with HBSS-Gel. Portions $(100 \mu \mathrm{l})$ of each of the four components were mixed. Control tubes were run with each assay by omitting antibody, complement or PMN and substituting $100 \mu \mathrm{lBBS}-\mathrm{Gel}$. The mixtures were held at $37^{\circ} \mathrm{C}$ and constantly rotated end-over-end for $2 \mathrm{~h}$. A small portion was removed, mixed with 10 vols distilled water to disrupt the PMN, serially diluted with saline and plated to determine the bacterial counts. The plates were incubated overnight at $37^{\circ} \mathrm{C}$, and the c.f.u. were counted. Mean c.f.u. and standard deviations (SD) were calculated from experiments done in triplicate. The $t$-test was applied to determine the significance of differences.

Protective activity of human Mabs against $P$. aeruginosa infection. Three experimental models were used.

(i) Intraperitoneal (i.p.) administration of human Mab before i.p. challenge. A group of 10 ICR mice (4 weeks old, males) was injected i.p. with $0.5 \mathrm{ml}$ serially-diluted human Mab. Two hours after injection the animals were challenged i.p. with $P$. aeruginosa $\left(2-4 \mathrm{LD}_{50}\right)$. The $\mathrm{LD}_{50}$ for strains 122 , IT-2, IT-3, NC5 and IT-4 was calculated to be $1 \times 10^{6}, 5 \times 10^{6}, 2 \times 10^{6}, 5 \times 10^{5}$ and $5 \times 10^{6}$, respectively. The control mice were administered PBS. The animals were observed for $5 \mathrm{~d}$ after challenge.

(ii) Administration of human Mab after subcutaneous (s.c.) challenge at a burned site. This test was done as described by Stieritz \& Holder (1975). A group of 10 ICR mice (4 weeks old, males) was anaesthetized by injecting Nembutal (Abbott Laboratories), and then a $3 \mathrm{~cm}^{2}$ burn was created on the shaved back by burning for $10 \mathrm{~s}$ with a low flame of a gas burner. Immediately after burning, $10^{5}$ c.f.u. $\left(20 \mathrm{LD}_{50}\right)$ of $P$. aeruginosa $\mathrm{NC} 5 \mathrm{in} 0.2 \mathrm{ml} 0.9 \%$ $\mathrm{NaCl}$ were injected s.c. into the burned site. Two hours after challenge, Mab P8-1 in $0.5 \mathrm{ml}$ of PBS was injected intravenously. The animals were observed for $6 \mathrm{~d}$ after challenge.

(iii) I.p. administration before i.p. challenge of leucopenic mice. A group of $10 \mathrm{ICR}$ mice (4 weeks old, males) was rendered leucopenic by three i.p. injections of cyclophosphamide $(100-150 \mu \mathrm{g}$ per g weight of mouse) in $0.5 \mathrm{ml}$ PBS on days 1,3 and 5 . Leucopenia ( $\leqslant 1000$ leucocytes per $\mathrm{ml}$ blood) was seen on day 5 . The mice were injected i.p. with $0.5 \mathrm{ml}$ of serially-diluted Mab P8-1 on day 5. One hour after injection, $10^{4}$ c.f.u. $\left(10 \mathrm{LD}_{50}\right)$ of $P$. aeruginosa $\mathrm{NC5}$ in $0.5 \mathrm{ml} 0.9 \% \mathrm{NaCl}$ were injected i.p. The animals were observed for $5 \mathrm{~d}$ after challenge. The mean protective dose $\left(\mathrm{PD}_{50}\right)$, i.e. the dose of each $\mathrm{Mab}$ able to protect half the animals in the group, was calculated by probit analysis. 


\section{RESULTS \\ Production of human Mabs}

Human lymphocytes (21 preparations of PBL, and 76 of tonsillar cells) were cultured in vitro in the presence of PWM for $6 \mathrm{~d}$, and then the presence of antibody to P. aeruginosa LPS was examined by ELISA. No antibody response to $P$. aeruginosa LPS was obtained when PBL were cultured with PWM. Although most tonsillar cell cultures, such as nos 83 and 91 , failed to produce specific antibody to $\boldsymbol{P}$. aeruginosa, five tonsil samples did secrete specific IgG antibody to $P$. aeruginosa LPS (Table 1). They were nos 31 (specific for serotype $E$ and $G$ ), 63 (specific for B), 66 (specific for A), 77 (specific for B and G) and 105 (specific for I). We used these five kinds of tonsillar cells for fusion. After $4 \mathrm{~d}$ culture of the selected lymphocytes in RPMI 1640 medium containing $10 \%$ FCS, the lymphocytes were washed with serum-free RPMI 1640 medium and then fused with the nonsecreting mouse myeloma P3U1. Fusion was performed 10 times in total throughout the experiment. Hybridomas grew in 2-3 weeks. About 5000 wells containing hybridomas were obtained. The efficiency of appearance of hybridomas was calculated to be $1 \times 10^{-4}$ per lymphoctyte.

The supernatant of each well was transferred to 96-well plates coated with a mixture of strains of the five major serotypes (see Methods) and assay was performed by ELISA using alkaline phosphatase-labelled anti-human $\operatorname{IgG}$ as the second antibody. Each hybridoma whose supernatant gave a positive score was cloned by limiting dilution. The supernatant of each cloned hybridoma was assayed again, and 25 clones were found to secrete antibody reactive with the mixture of strains. Their binding specificity to 14 different Homma standard serotype strains was next determined by ELISA. From among the 25 clones, we selected five human Mabs, P1-1, P5-1, P7-1, P8-1 and P10-1 (derived from tonsillar lymphocyte cultures 66, 31, 63, 77 and 105 , respectively), because they were stably produced and their hybridomas grew well. The ELISA binding specificities of these five human Mabs are shown in Table 2. P1-1, P5-1, P7-1, P8-1 and P10-1 reacted specifically with serotypes A, E, B, G and I, respectively, and bound completely to the respective serotype strains tested. In total, more than 70 strains of different serotypes were examined. The same results as shown in Table 2 were obtained. The Mabs did not bind to other serotypes or to other Gram-negative bacterial strains (data not shown). Karyotypic analysis of the hybridoma cells demonstrated a polyploid chromosome number with chromosomes of both human and murine origin; for example, the mean chromosome number of P5-1 was 98, whereas for the parent P3U1 it was 58. Antisera directed against mouse heavy or light chains, which detect $1-10 \mathrm{ng}$ murine immunoglobulin $\mathrm{ml}^{-1}$ in ELISA, failed to react with the supernatants of these hybridomas. The concentration of each human Mab in $2 \mathrm{~d}$ cultures ranged from 10 to $20 \mu \mathrm{g} \mathrm{m}^{-1}$.

\section{Recognition site}

Each human Mab was transferred to an LPS-coated plate to examine its reactivity with LPS. All the human Mabs reacted with the corresponding serotypes. To identify further the recognition site, PAO-1 LPS (serotype B) was hydrolysed with acetic acid to yield A-PS, which was fractionated by Sephadex G-50 column chromatography (Fig. 1). Three peaks were detected by assay for hexose and hexosamine. Fraction I contained a large amount of hexosamine and a small amount of hexose, and $\mathrm{O}$-antigen was eluted in this fraction as revealed by the inhibition test using rabbit IgG specific for the $\mathrm{O}$-antigen of serotype B. Fraction II was composed of hexose, hexosamine and phosphorus (Sawada et al., 1985 b), and the core antigen was eluted in this fraction (Wilkinson \& Galbraith, 1975). Fraction III consisted mainly of phosphorus and 2-keto-3-deoxyoctonate (Sawada et al., 1985 b). Activity blocking the binding of P7-1 to strain PAO-1 cells was found to be in fraction I (Fig. 1). Blocking activity was also observed in fraction I for each of P1-1, P5-1, P8-1 and P10-1 when the same experiment was done using the corresponding serotype LPS.

\section{Agglutination activity}

Agglutination activity was examined in 96-U-well plates. P1-1, P5-1, P7-1, P8-1 and P10-1 agglutinated the respective homologous strains: 122 (serotype A), IT-2 (E), IT-3 (B), NC5 (G) 
Table 1. $P$. aeruginosa-specific IgG production by $P W M$-stimulated tonsillar cells

\begin{tabular}{|c|c|c|c|c|c|}
\hline \multirow{2}{*}{$\begin{array}{l}\text { Tonsillar } \\
\text { cell } \\
\text { culture no. }\end{array}$} & \multicolumn{5}{|c|}{ Specific IgG production* to serotype } \\
\hline & A & E & B & $\mathrm{G}$ & I \\
\hline 31 & $0 \cdot 1$ & 1.4 & 0.0 & $1 \cdot 3$ & \\
\hline 63 & 0.0 & 0.1 & $1 \cdot 2$ & $0 \cdot 1$ & \\
\hline 66 & 1.2 & 0.2 & $0 \cdot 2$ & $0 \cdot 3$ & \\
\hline 77 & $0 \cdot 1$ & $0 \cdot 1$ & $1 \cdot 2$ & $1 \cdot 1$ & \\
\hline 83 & $0 \cdot 2$ & 0.0 & 0.0 & $0 \cdot 1$ & 0.0 \\
\hline 91 & $0 \cdot 1$ & 0.0 & 0.0 & 0.0 & $0 \cdot 1$ \\
\hline 105 & 0.0 & 0.1 & $0 \cdot 1$ & 0.0 & 4 \\
\hline
\end{tabular}

* ELISA score, expressed as $A_{405}$ after 30 min incubation.

Table 2. Binding of Mabs to P. aeruginosa strains of different serotype

In all assays, $5 \times 10^{6}$ formalin-killed whole cells were used as antigen and $1 \mu \mathrm{g}$ Màb as antibody. Results are recorded as $A_{405}$ after $60 \mathrm{~min}$. The background reading $(0 \cdot 1)$ was subtracted from each reading. A blank space indicates a zero reading.

\begin{tabular}{|c|c|c|c|c|c|c|c|c|c|c|c|}
\hline \multirow[b]{2}{*}{ Strain } & \multicolumn{5}{|c|}{ ELISA reading } & \multirow[b]{2}{*}{ Strain } & \multicolumn{5}{|c|}{ ELISA reading } \\
\hline & P1-1 & P5-1 & P7-1 & P8-1 & P10-1 & & P1-1 & P5-1 & P7-1 & P8-1 & P10-1 \\
\hline $\begin{array}{l}\text { Serotype A } \\
\text { ATCC } 27577 \\
\text { C-8 } \\
122 \\
\mathrm{~N}-1\end{array}$ & $\begin{array}{l}1.5 \\
1.7 \\
1.8 \\
1.8\end{array}$ & & & & & $\begin{array}{l}\text { Serotype F } \\
\text { ATCC } 27582 \\
64 \\
\text { Serotype G } \\
\text { ATCC } 27584\end{array}$ & & & & 1.5 & \\
\hline $\begin{array}{l}\text { Serotype B } \\
\text { ATCC } 27578 \\
\text { ATCC } 27583 \\
\text { ATCC } 27589 \\
\text { PAO-1 } \\
97 \\
\text { IT-3 } \\
\text { IT-7 }\end{array}$ & & & $\begin{array}{l}1.3 \\
1.5 \\
1.2 \\
1.9 \\
1.9 \\
1.9 \\
2.0\end{array}$ & & & $\begin{array}{l}\text { IT-1 } \\
\text { NC5 } \\
\text { O7 } \\
\text { Serotype } H \\
\text { ATCC } 27585 \\
\text { IT-5 } \\
1258\end{array}$ & & & & $\begin{array}{l}1.9 \\
1.7 \\
1.8\end{array}$ & \\
\hline $\begin{array}{l}\text { IT-7 } \\
\text { Serotype C } \\
\text { ATCC } 27579 \\
\text { IT-6 }\end{array}$ & & & & & & $\begin{array}{l}\text { Serotype I } \\
\text { ATCC } 27586 \\
\text { IT-4 } \\
38\end{array}$ & & & & & $\begin{array}{l}1.6 \\
1.6 \\
1.7\end{array}$ \\
\hline $\begin{array}{l}\text { Serotype E } \\
\text { ATCC } 27581 \\
\text { IT-2 } \\
\text { N-2 } \\
\text { O101 } \\
\text { C-12 }\end{array}$ & & $\begin{array}{l}1.5 \\
1.9 \\
1.8 \\
1.9 \\
1.8\end{array}$ & & & & & & & & & \\
\hline
\end{tabular}

and IT-4 (I). The endpoint antibody concentrations of P1-1, P5-1, P8-1 and P10-1 causing agglutination were calculated to be $1.5,3 \cdot 1,6 \cdot 2$ and $6.2 \mu \mathrm{g} \mathrm{ml}^{-1}$, respectively, but a higher concentration $\left(25.0 \mu \mathrm{g} \mathrm{ml}^{-1}\right)$ of P7-1 was necessary to cause agglutination.

\section{Opsonophagocytic killing activity}

Fig. 2 shows the viable counts after 2 h phagocytosis, with Mabs P1-1, P7-1, P8-1 and P5-1. When all the components (PMN, Mab, complement) were incubated, all four Mabs showed more than $90 \%$ reduction of the c.f.u., to values significantly lower than those of control experiments without $\mathrm{Mab}(P<0.01)$. Mabs $\mathrm{P} 1-1$ and $\mathrm{P} 7-1$ showed killing activity against strains 122 and IT-3, respectively without complement $(P<0 \cdot 01)$. When P7-1 (serotype B specific) was added instead of P8-1 (G specific), no opsonophagocytic killing activity of the serotype G strain IT-1 was observed (Fig. 2 c). The other serotype-specific human Mab, P10-1, similarly showed opsonophagocytic killing activity against strain IT-4 (serotype I) (data not shown). 


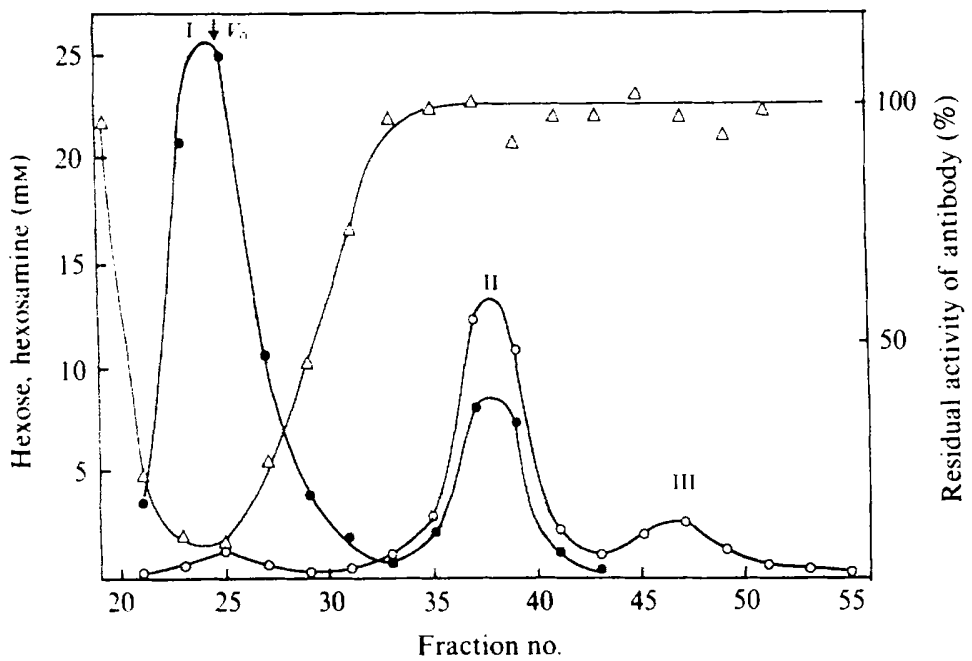

Fig. 1. Elution profile of A-PS released from $P$. aeruginosa strain PAO-1 (serotype B) after hydrolysis with $1 \%$ acetic acid at $100{ }^{\circ} \mathrm{C}$ for $2 \mathrm{~h}$. The material was eluted from a Sephadex G-50 column $(33 \times 1.5 \mathrm{~cm})$ with $50 \mathrm{~mm}$-pyridine/acetate buffer, $\mathrm{pH} 4.2$. Fractions of $1 \mathrm{ml}$ were collected, and portions were assayed for hexose $(O)$, hexosamine $(O)$ and percentage residual activity of human Mab P7.1 $\triangle$ ). O-antigen was eluted in the void volume (as revealed by the inhibition test using rabbit antiserum to $\mathrm{O}$-antigen of $P$. aeruginosa serotype B).

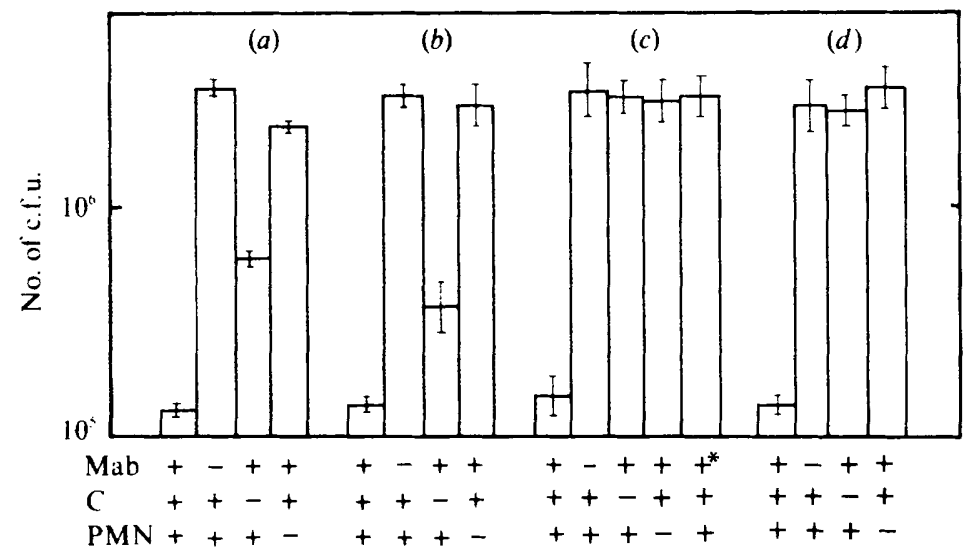

Fig. 2. Opsonophagocytic killing of $P$. aeruginosa by human Mabs. Control tubes were run with each assay by omitting Mab, complement (C) or PMN as indicated, and substituting $100 \mu \mathrm{HBSS}-\mathrm{Gel}$. The plates were incubated overnight at $37^{\circ} \mathrm{C}$, and c.f.u. were counted the next day. Results are the mean of three independent observations \pm SD. The following human Mabs and $P$. aeruginosa strains were used: (a) P1-1, 122; (b) P7-1, IT-3; (c) P8-1, IT-1 (*P7-1 added instead of P8-1); (d) P5-1, IT-2.

\section{In vivo protection}

Four-week-old male ICR mice were injected i.p. with human Mabs, and $2 \mathrm{~h}$ later they were challenged by i.p. injection of virulent strains which secreted exotoxin $A$, elastase and/or protease (Table 3). On the basis of their PD $_{50}$ values, Mabs PI-1, P5-1, P8-1 and P10-1 were highly active, while P7-1 was moderately active. P5-1 and P8-1 did not protect the mice from challenge with mismatched serotype strains IT-4 and 122, respectively; thus these Mabs conferred serotype-specific immunoprotection. Table 3 also shows that protection was achieved even when exoprotein-producing strains were used for the challenge.

We estimated the protective activity of P8-1 against infection in burned and leukopenic mice. In the burned mouse model, the $P_{50}$ value of P8-1 against infection was calculated to be $0.6 \mu \mathrm{g}$ 
Table 3. Protective activity of human Mabs against i.p. infection by P. aeruginosa

\begin{tabular}{|c|c|c|c|c|c|c|}
\hline \multirow[b]{2}{*}{ Mab } & \multirow{2}{*}{$\begin{array}{l}\text { Serotype } \\
\text { specificity }\end{array}$} & \multirow{2}{*}{$\begin{array}{c}\text { Challenge } \\
\text { strain } \\
\text { (serotype) }\end{array}$} & \multirow{2}{*}{ 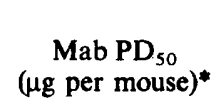 } & \multicolumn{3}{|c|}{ Exoproduct synthesis $\dagger$} \\
\hline & & & & ExA & Ela & Pro \\
\hline P1-1 & A & $122(\mathrm{~A})$ & $\begin{array}{c}0 \cdot 3 \\
(0 \cdot 2-0 \cdot 8)\end{array}$ & NT & NT & NT \\
\hline P5-1 & E & IT-2 (E) & $\begin{array}{c}0.5 \\
(0.3-0.8)\end{array}$ & + & + & - \\
\hline P5-1 & $\mathrm{E}$ & IT-4 (I) & $>100$ & + & + & + \\
\hline P8-1 & G & NC5 (G) & $\begin{array}{c}0.8 \\
(0.4-2.0)\end{array}$ & t & + & + \\
\hline P8-1 & G & $122(\mathrm{~A})$ & $>100$ & NT & NT & NT \\
\hline P7-1 & B & IT-3 (B) & $\begin{array}{c}4 \cdot 2 \\
(1 \cdot 8-9 \cdot 8)\end{array}$ & + & + & + \\
\hline P10-1 & I & IT-4 (I) & $\begin{array}{c}0 \cdot 5 \\
(0 \cdot 2-1 \cdot 2)\end{array}$ & + & + & + \\
\hline
\end{tabular}

NT, Not tested.

- The corresponding $95 \%$ confidence limits are given in parenthesis below each $\mathrm{PD}_{50}$.

† ExA, exotoxin A; Ela, elastase; Pro, protease.

Table 4. Summary of characteristics of anti-P. aeruginosa human Mabs

\begin{tabular}{|c|c|c|c|c|c|}
\hline & P1-1 & P5-1 & P7.1 & P8-1 & P10-1 \\
\hline Isotype & $\operatorname{IgG} 2, \kappa$ & $\operatorname{IgG} 2, \lambda$ & $\operatorname{IgG} 2, \lambda$ & $\operatorname{IgG} 2, \lambda$ & $\operatorname{IgG} 2, \kappa$ \\
\hline Antigen & 0 & 0 & 0 & o & 0 \\
\hline Binding specificity & A & E & B & G & I \\
\hline Agglutination activity & + & + & + & + & + \\
\hline Opsonophagocytic killing & + & + & + & + & + \\
\hline In vivo (mouse) protection & ++ & ++ & + & $+t$ & ++ \\
\hline Productivity ( $\mu \mathrm{g}$ per $10^{6}$ cells in $24 \mathrm{~h}$ ) & 10 & 12 & 15 & 20 & 10 \\
\hline Stability (months) & $>18$ & $>20$ & $>15$ & $>16$ & $>14$ \\
\hline Growth in serum-free culture & Yes & Yes & Yes & Yes & Yes \\
\hline
\end{tabular}

( $95 \%$ confidence limits $0.4-0.9 \mu \mathrm{g})$ per mouse, whereas that of NHIgG was $1270 \mu \mathrm{g}(683-$ $2390 \mu \mathrm{g})$ per mouse. In the leukopenic mouse model, the PD $_{50}$ values of P8-1 and NHIgG were $0.5 \mu \mathrm{g}(0 \cdot 3-1.3 \mu \mathrm{g})$ and $1320 \mu \mathrm{g}(497-3500 \mu \mathrm{g})$ per mouse, respectively.

\section{Mab productivity and stability}

Because human $\times$ mouse hybridomas tend to stop secreting human Mabs, some hybridomas that seemed to be promising were further cloned to establish stable clones. Four or five additional cloning steps were usually needed. These established hybridomas have been producing human Mabs for more than 14 months. Their characteristics are summarized in Table 4. All of them have been adapted to grow in serum-free medium and have been producing 10-20 $\mu \mathrm{g}$ human Mab per $10^{6}$ cells in $24 \mathrm{~h}$ for more than 3 months.

\section{DISCUSSION}

Formation of hybridomas (Croce et al., 1980a; Schwaber, 1975) and transformation with Epstein-Barr virus (EBV) (Kozbor et al., 1979; Boylston et al., 1980) are well-known methods for production of human Mabs. Since most EBV-transformed cells from normal adults produce IgM (Brown \& Miller, 1982), we preferred the hybridoma method to obtain IgG producers because IgG is expected to diffuse better in tissues and is much easier to purify than $\operatorname{IgM}$. The lack of any suitable human myeloma cell line having a high fusion efficiency required us to use a mouse myeloma instead. 
We obtained human Mabs which bound with LPS by fusing nonsecreting mouse myeloma cells and human lymphocytes. We thought it important to select a human lymphocyte source capable of yielding antigen-specific hybridomas through fusion with mouse myeloma cells. For this purpose, we examined the supernatants of PWM-stimulated cultures of PBL and tonsillar cells from 21 and 76 patients, respectively. No antibody response was observed with any of the PBL sources. One reason for this may be the small number of B lymphocytes in PBL. Only five of the 76 tonsillar cell cultures produced IgG antibody specific for $P$. aeruginosa LPS. Twenty-five hybridomas producing antibody against $P$. aeruginosa were obtained from these five tonsillar cell cultures. The positive response in ELISA of PWM-stimulated lymphocytes could be a reflection of the increased number of antigen-specific B cells in the lymphocyte source. We think that this method can probably be applied to obtain human Mabs specific for other antigens. Regarding the IgG isotype, the $\mathrm{H}$ chains of each of the five human Mabs were IgG2, and three of them had $\lambda \mathrm{L}$ chains. Besides the five human Mabs described in this report, we have developed more than 20 human Mabs specific for $P$. aeruginosa LPS. All of them are IgG2, and $80 \%$ of them contain $\lambda$ chains. Since earlier studies suggested that human antibodies to bacterial polysaccharide are largely restricted to the IgG2 subclass (Yount et al., 1968; Siber et al., 1980), the fact that all the $\mathrm{H}$ chains were IgG2 was thought to be a reflection of human immunity. The high frequency of $\lambda$ type seems to arise from the human $x$ mouse hybridoma method itself: because hybridomas derived from human lymphocytes and mouse myeloma cells easily segregate human chromosome 2 (Croce et al., 1980b), which carries the DNA coding for the $\kappa$ chain, $\kappa$-chain-producing hybridomas are difficult to establish as stable clones. It has been said that the crucial problem with human $\times$ mouse hybridomas lies in their instability in terms of long-term secretion of antibody (Croce et al., $1980 \mathrm{~b}$; Ruddle, 1973). We solved this problem by repeated cloning. Stable clones secreting 10-20 $\mu \mathrm{g}$ human Mab per $10^{6}$ cells in $24 \mathrm{~h}$ for more than 3 months in serum-free medium can be established, as demonstrated in this report. Our colleagues have also reported the successful establishment of stable human $\times$ mouse hybridomas showing long-term secretion of human Mabs against Herpes simplex virus (Masuho et al., 1986) and cytomegalovirus (Matsumoto et al., 1986). These results suggest that human $\times$ mouse hybridomas are suitable for stable production of human Mabs.

Antibodies reactive with the O-antigen of LPS act as opsonins, increasing the efficiency of phagocytosis and killing of $P$. aeruginosa by host phagocytes (Young, 1972), and they have the ability to protect mice against lethal Pseudomonas infection (Cryz et al., 1983). These results were obtained by using polyclonal antibodies. Since an Mab recognizes only one epitope on the antigen molecule, formation of a dense antigen-antibody lattice complex is thought to be difficult. Hence, there might be some doubt whether an Mab could augment bacterial agglutination, opsonization and in vivo protective activity. We prepared murine Mabs specific for Homma serotype 7, and found them to have protective activity against infection with $P$. aeruginosa (Sawada et al., 1984). Two recent reports have documented the preparation of serotype-specific Mabs against $P$. aeruginosa LPS. Stoll et al. (1986) reported a murine Mab (IgG1) specific for Fisher IT-1 strain that has opsonic activity and protects burned mice against s.c. challenge with homologous strains. Barclay et al. (1986) described 18 murine Mabs of isotype IgG1, IgG2b, IgG3 or IgM that protected mice at a very low dose. Especially in the latter report, the amount of antibody necessary to show protective activity was calculated to be less than $10 \mathrm{ng}$ per mouse, which represents 10 - to 100 -fold more potent protective activity than that of our murine Mabs. We think, however, that the protective activities of their Mabs are extraordinarily high, and we wonder why the protective titre of the Mabs exceeded their ELISA titre. As discussed above, murine Mabs specific for O-antigen have been proved to be protective in mice, but they can not be administered to man because of their immunogenicity. For this reason, we attempted to develop human Mabs.

Human Mabs P1-1, P5-1, P7-1, P8-1 and P10-1 recognized O-antigens of the five major serotypes of $P$. aeruginosa because they bound serotype-specifically with LPS, and their binding to $P$. aeruginosa was inhibited by Sephadex G-50 fraction I (see Fig. 1), which is considered to contain O-antigen. Fraction I contained a large amount of hexosamine and a small amount of 
hexose, findings in accordance with the nature of the O-antigen (Wilkinson, 1983). Young (1972) reported an important role for the opsonic activity of human antibody, which was serotype-specific. All of our human Mabs showed opsonic activity. High agglutinating activity was also observed for all the Mabs except P7-1, which had moderate activity. All the Mabs had high protective activity against peritoneal infection in normal mice, again except for P7-1, which was moderately active. These results suggest that, besides opsonic activity, human Mabs having high agglutinating activity appear to be more protective than those with moderate agglutinating activity. One possible explanation could be that the binding sites of the moderately agglutinating Mab P7-1 are deeper in the cell wall structure than those of the highly agglutinating Mabs, i.e. the highly agglutinating Mabs bind to the exposed end of the $\mathrm{O}$ side chain of LPS, whereas the moderately agglutinating P7-1 binds to the base of the $O$ side chain. In fact, since P7-1 reacted with three sub-serotype strains (ATCC 27578, 27583 and 27589) which belong to serotype $B$, it is possible that $P 7-1$ recognizes the common antigen of serotype $B$, which is at the base of the $\mathrm{O}$ side chain. Because the $\mathrm{O}$ side chain is long, an antibody molecule bound to the deep site would not protrude enough to bind to a corresponding antigenic site on another bacterial cell, and thus sufficient 'bridges' for agglutination would not be formed between the bacterial cells. An alternative explanation for the moderate protective activity of P7-1 might lie in the binding affinity. We previously reported that a human Mab (P3D9) specific for Homma serotype 5 was nonagglutinating and protective (Sawada et al., 1985a). In the work described in that report, P3D9 was diluted from $1 \mu \mathrm{g}$ antibody $\mathrm{ml}^{-1}$ to measure the agglutination activity because we expected it to show high agglutination activity. After publication, when we reexamined the agglutination activity, $\mathrm{P} 3 \mathrm{D} 9$ alone agglutinated strain $\mathrm{N}-2$ at a concentration of $6 \cdot 2-12 \cdot 4 \mu \mathrm{g} \mathrm{ml}^{-1}$. In contrast to the original report, P3D9 was thus both agglutinating and protective.

Hyperimmune intravenous immunoglobulin preparations which are prepared from high-titre plasma have now been developed. The protective activity of a high-titre preparation against $P$. aeruginosa was reported to be up to five times higher than that of conventional intravenous IgG (Collins \& Roby, 1984). Since the human Mabs described in this report show 2000 times higher protective activity than conventional NHIgG, passive immunization with human Mabs is surmised to be capable of achieving prophylaxis and treatment of Pseudomonas diseases.

\section{REFERENCES}

Barclay, G. R., YaP, P. L., McClelland, D. B. L., Jones, R. J., Roe, E. A., McCanN, M. C., MrCKlem, L. R. \& JAMES, K. (1986). Characterization of mouse monoclonal antibodies produced by immunisation with a single serotype component of a polyvalent Pseudomonas aeruginosa vaccine. Journal of Medical Microbiology 21, 87-90.

BERTANI, G. (1951). Studies of lysogenesis. I. The mode of phage liberation by lysogeneic Escherichia coli. Journal of Bacteriology 62, 293-300.

Bodey, G. P. \& Rodriquez, V. (1973). Advances in the management of Pseudomonas aeruginosa in cancer patients. European Journal of Cancer 9, 435441.

Boylston, A. W., Gardner, B., Anderson, R. L. \& Hughes-Jones, W. C. (1980). Production of human IgM anti-D in tissue culture by EB-virus transformed lymphocytes. Scandinavian Journal of Immunology 12, 355-358.

Brown, N. A. \& Miller, G. (1982). Immunoglobulin expression by human B lymphocytes clonally transformed by Epstein-Barr virus. Journal of Immuno$\log y$ 128, 24-29.
Collins, M. S. \& Roby, R. E. (1984). Protective activity of an intravenous immune globulin (human) enriched in antibody against lipopolysaccharide antigens of Pseudomonas aeruginosa. American Journal of Medicine 75, 3A, 168-174.

Croce, C. M., Linnenbach, A., Hall, W., StePLEWSKI, Z. \& KoprowSKI, H. (1980a). Production of human hybridomas secreting antibodies to measles virus. Nature, London 288, 488-489.

Croce, C. M., Shander, M., Martinis, J., Cicurel, L., D'Ancona, G. G. \& Koprowski, H. (1980b). Preferential retention of human chromosome 14 in mouse $\times$ human $B$ cell hybrids. European Journal of Immunology 10, 486 488 .

Cryz, S. J., JR, Furer, E. \& Germanier, R. (1983). Protection against $P$ seudomonas aeruginosa infection in a murine burn wound sepsis model by passive transfer of antitoxin A, antielastase, and antilipopolysaccharide. Infection and Immunity 39, 1072-1079.

FiSHER, M. W. (1977). A polyvalent human $\gamma$-globulin immune to Pseudomonas aeruginosa: passive protection of mice against lethal infection. Journal of Infectious Diseases 136 (supplement), S181-S185. 
Hoiby, W. \& Olling, S. (1977). Pseudomonas aeruginosa infection in cystic fibrosis. Acta pathologica et microbiologica scandinavica C85, 107-114.

Johnson, K. G. \& PerRY, M. B. (1976). Improved techniques for the preparation of bacterial lipopolysaccharides. Canadian Journal of Microbiology 22, 29-34.

King, A., Shannon, K., Eykyn, S. \& Phillips, I. (1983). Reduced sensitivity of $\beta$-lactam antibiotics arising during ceftazidine treatment of Pseudomonas aeruginosa infections. Journal of Antimicrobial Chemotherapy 12, 363-370.

KOZboR, D., Steinitz, M., KLeIN, G., Kosikimies, S. \& Makala, O. (1979). Establishment of anti-TNP antibody-producing human lymphoid lines by preselection for hapten binding followed by EBV transformation. Scandinavian Journal of Immunology 10, 187-194.

LAEMMLI, U. K. (1970). Cleavage of structural proteins during the assembly of the head of bacteriophage T4. Nature, London 227, 680-685.

Liu, P. V., Matsumoto, H., Kusama, H. \& Bergan, T. (1983). Survey of heat-stable major somatic antigens of Pseudomonas aeruginosa. International Journal of Systematic Bacteriology 33, 256-264.

LOWBURY, E. J. L. \& JONES, R. J. (1975). Treatment and prophylaxis for Pseudomonas infections. In Resistance to Pseudomonas aeruginosa, pp. 237-269. Edited by M. R. W. Brown. New York: John Wiley.

Masuho, Y., Sugano, T., Matsumoto, Y., Sawada, S. \& TOMIBE, K. (1986). Generation of hybridomas producing human monoclonal antibodies against herpes simplex virus after in vitro stimulation. Biochemical and Biophysical Research Communications 135, 495-500.

Matsumoto, Y., Sugano, T., MiYamoto, C. \& MAsuHo, Y. (1986). Generation of hybridomas producing human monoclonal antibodies against human cytomegalovirus. Biochemical and Biophysical Research Communications 137, 273-280.

Murakami, H., Masui, H., Sato. G. H., Sueoka, N., Chow, T. P. \& SuENoKA, T. K. (1982). Growth of hybridoma cells in serum-free medium: ethanolamine is an essential component. Proceedings of the National Academy of Sciences of the United States of America 79, 1158-1162.

Pruit, B. A. JR (1974). Infections caused by Pseudomonas species in patients with burns and in other surgical patients. Journal of Infectious Diseases 130 (supplement), S8-S13.

RUDDLE, F. H. (1973). Linkage analysis in man by somatic cell genetics. Nature, London 242, 165-166.

Sato, K., Ueda, K., Saito, N., Kikuchi, H., MatsuMIYA, H. \& SATTO, R. (1981). Incidence of Pseudomonas aeruginosa in Hokkaido University Hospital. In Proceedings of the 15th meeting of the Japan Pseudomonas aeruginosa Society, pp. 61-62. Edited by J. Y. Homma. Tokyo: Kitasato Institute.
Sawada, S., Suzuki, M., Kawamura, T., Fujinaga, S., Masuho, Y. \& Tomibe, K. (1984). Protection against infection with Pseudomonas aeruginosa by passive transfer of monoclonal antibodies to lipopolysaccharides and outer membrane proteins. Journal of Infectious Diseases 150, 570-576.

Sawada, S., Kawamura, T., Masuho, Y. \& Tomibe, K. (1985a). Characterization of a human monoclonal antibody to lipopolysaccharides of Pseudomonas aeruginosa serotype $5:$ a possible candidate as an immunotherapeutic agent for infections with $P$. aeruginosa. Journal of Infectious Diseases 152, 965970.

Sawada, S., Kawamura, T., Masuho, Y. \& Tomibe, K. (1985b). A new common polysaccharide antigen of strains of Pseudomonas aeruginosa detected with a monoclonal antibody. Journal of Infectious Diseases 152, 1290-1299.

SCHWABER, J. (1975). Immunoglobulin production by a human-mouse somatic cell hybrid. Experimental Cell Research 93, 343-354.

Siber, G. R., SCHUR, P. H., AISENBerg, A. C., Wetrzman, S. A. \& Schiffman, G. (1980). Correlation between serum $\mathrm{IgG}-2$ concentrations and the antibody response to bacterial polysaccharide antigens. New England Journal of Medicine 303, 178-182.

Stieritz, D. D. \& Holder, I. A. (1975). Experimental studies of the pathogenesis of infections due to Pseudomonas aeruginosa: description of a burned mouse model. Journal of Infectious Diseases 131, 688691.

Stoll, B. J., Pollack, M., Young, L. S., Koles, N., Gascon, R. \& PIER, G. B. (1986). Functionally active monoclonal antibody that recognizes an epitope on the $O$ side chain of Pseudomonas aeruginosa immunotype-1 lipopolysaccharide. Infection and Immunity 53, 656-662.

WILkinson, S. G. (1983). Composition and structure of lipopolysaccharides from Pseudomonas aeruginosa. Reviews of Infectious Diseases 5, S941-S949.

Wilkinson, S. G. \& Galbraith, L. (1975). Studies of lipopolysaccharides from Pseudomonas aeruginosa. European Journal of Biochemistry 52, 331-343.

Yelton, D. E., Diamond, B. A., Kwan, S. P. \& SCHARFF, M. D. (1978). Fusion of mouse myeloma and spleen cells. Current Topics in Microbiology and Immunology 81, 1-7.

Young, L. S. (1972). Human immunity to Pseudomonas aeruginosa. II. Relationship between heat-stable opsonins and type-specific lipopolysaccharides. Journal of Infectious Diseases 126, 277-287.

YOUNT, W. J., DORner, N. M., Kunkel, H. G. \& KABAT, E. A. (1968). Studies on human antibodies. VI. Selective variations in subgroup composition and genetic markers. Journal of Experimental Medicine 127, 633-646. 